\title{
How Technology Supports Family Communication in Rural, Suburban, and Urban Kenya
}

\author{
Erick N. O. Oduor ${ }^{1}$, Carman Neustaedter ${ }^{1}$, Tejinder K. Judge ${ }^{2}$, Kate Hennessy ${ }^{1}$, Carolyn Pang ${ }^{1}$, and Serena Hillman ${ }^{1}$ \\ School of Interactive Arts and Technology ${ }^{1}$ \\ Simon Fraser University \\ 250-13450 102nd Avenue, Surrey BC, Canada \\ [firstname_secondname]@sfu.ca \\ Google Inc. ${ }^{2}$ \\ 1900 Charleston Rd, \\ Mountain View, CA, 94043, USA \\ tkjudge@google.com
}

\begin{abstract}
Much ICTD research for sub-Saharan Africa has focused on how technology related interventions have aimed to incorporate marginalized communities towards global economic growth. Our work builds on this. We present results from an exploratory qualitative study on the family communication practices of family members who communicate both within and between rural, suburban, and urban settings in Kenya. Our findings reveal that family communication focuses on economic support, well-being, life advice, and everyday coordination of activities. We also outline social factors that affect family communication, including being an eldest child, having a widowed sibling, and having reduced access to technology because of gender, literacy, or one's financial situation. Lastly, we discuss new opportunities for technology design and articulate the challenges that designers will face if creating or deploying family communication technologies in Kenya.
\end{abstract}

\section{ACM Classification Keywords}

H.5.3 [Information interfaces and presentation]: Group and Organization Interfaces - Computer Supported Cooperative Work

\section{Author Keywords}

ICT4D, family communication, awareness, mobile devices

\section{INTRODUCTION}

There exists a growing amount of research on communication practices in developing countries (e.g., $[16,21,25,27,31])$ with a specific emphasis on the effects of poverty, educational levels, and a lack of technological infrastructure. Our focus is on understanding the use of technology in Kenya for family communication. Within this space, we have seen studies that have explored how Kenyans living abroad use technology to communicate with their families who are 'back home' in Kenya [33], how technologies are used in different ways than in developed

Permission to make digital or hard copies of all or part of this work for personal or classroom use is granted without fee provided that copies are not made or distributed for profit or commercial advantage and that copies bear this notice and the full citation on the first page. Copyrights for components of this work owned by others than ACM must be honored. Abstracting with credit is permitted. To copy otherwise, or republish, to post on servers or to redistribute to lists, requires prior specific permission and/or a fee. Request permissions from permissions@acm.org.

CHI 2014, April 26-May 1, 2014, Toronto, Ontario, Canada.

Copyright (C) 2014 ACM 978-1-4503-2473-1/14/04 ...\$15.00.

Add the DOI string/url from ACM e-form confirmation here. countries [36], how gender impacts cellphone adoption [7,21], and how rural-urban migration [1] and rural access of technology by women [16] affects communication.

Overall, this research provides a solid foundation for understanding technology usage in developing countries. Yet we see less research in terms of how technology supports family communication, in particular, from a Human-Computer Interaction perspective, largely focused on understanding technology design and its usage. Our research builds on the existing literature to address this gap.

Specifically, we explore how Kenyans from rural, suburban, and urban settings share information within family structures even in the midst of challenges that result from continuous rural-urban migration [1]. To do this, we conducted an exploratory study involving in-depth interviews with 24 participants living in various regions of Kenya. Our goal was to uncover family communication practices that were technology-based and understand how families adopted the use of technology in rural, suburban, and urban areas when faced with infrastructure limitations. We also aimed to understand when technology was used and why, and what social factors affected this usage. This moves beyond infrastructure-related issues such as a lack of connectivity or electricity, which have already been reported (e.g., [33 - 36]).

To foreshadow, our results show that communication over technology between distributed family members was primarily for coordinating economic and subsistence support for relatives, obtaining updates about family members' well-being, providing advice about life, and coordinating everyday family activities (albeit this depended on the setting). We also uncovered social practices that: created pressure for the eldest children in families to be nearly constantly available, required a brother-in-law of widowed women to take on additional communication, and led to an imbalance in terms of access to technology. The latter relates to gender issues, finances, and literacy. Together, these results illustrate the complexity of designing for family communication practices in Kenya. Rather than present design implications that suggest how to create family communication technology for Kenya, which may easily be speculative at best, we focus our discussion on broadening the focus of technology in Kenya and illustrate what social challenges designers will need to carefully think through when creating or deploying family communication technologies in Kenya. 


\section{RELATED WORK}

ICTD studies have highlighted the importance of understanding the dynamics and needs of local communities in developing countries before designing technology for them [29]. For example, Liu et al. [17] report on how rural Chinese families embraced the use of mobile phone entertainment. Rangaswamy \& Sambasivan [24] documented the local practices of individuals in Bangalore, India, and reported that ownership or use of technology could either be single or collective. Sambasivan et al. [25] reported on how the roles of women in slums in India shaped their selection and use of technology through intermediated interactions where 'digitally skilled users' helped those who lack technical skills. Sambasivan et al. [26] also described how technology supported social networks in Indian slums where a group of industry laborers living together used multiple ringtones to distinguish call recipients for a shared mobile phone. Even in cases of "social, technical, and environmental obstacles," motivation was found to be the driving force for the adoption and use of technology in developing areas [27].

Studies of family life in Jamaica [12] found that a significant number of low-income families depended on remittances from abroad, which were discussed over mobile phones $[11,12]$. Another study showed that El Salvadorian immigrants in North America used mobile phones to communicate with distributed family members back 'home' to discuss topics related to their kinship [30].

Several studies have looked at the use of cellphones and the use of callback in rural African communities. Burrell [5] found that gender segregation of space, social policing and economic dependence on husbands negatively impacted women's cellphone usage in Uganda. A considerable number did not have access to a cell phone unless they used their husband's or were gifted one. Husbands were typically concerned about 'secret' activities by their wives in case they (the wives) had a mobile phone. In a study conducted in the Mankosi region of South Africa, the interactions with an Audio Repository (AR) prototype showed that rural Africans preferred voice in cell-phone usage [3]. The authors suggest that researchers should aim to situate designs in 'local ways' so as to enrich the potential for asynchronous voice communication. Studies also showed that people prefer to use callback free messaging services rather than SMS because of its affordability and accessibility; this contrasts other services such as 'buzzing' that do not record missed calls on low end phones [4]. In post war Liberia, users saw their cellphones as productivity enhancers and means of connectivity to family and friends that could also be used as sources of personal security [2]. The idea of the phone as a stylish object was not considered to be important especially in rural areas [2]. Namibians reported the use of Facebook not only to share religious and political views, but also to share posts about death which are considered private and taboo by North Americans [22].
There also exist several studies focusing specifically on technology use in Kenya. Agesa and Kim [1] reported on split migration that occurs when a household head moves from a rural to an urban area for search of work. Eriksson [7] showed that cell phones bridged the gap between cities and rural areas in Kenya by providing job seekers with an opportunity to be reachable. Kwake and Adigun [16] looked at the use and access of Information and Communication Technologies (ICTs) amongst rural women in Kenya. Besides the marked correlation between the respondents' level of education, type of ICTs accessed and information needs and purposes, they observed that ICTs alone are insufficient for the emergence of significant benefits to rural women. Murphy and Priebe [21] provide an analysis of a census on the usage of cellphones in Bungoma, Kenya and describe how women often rely on borrowing a phone from someone or being gifted one. This reflects typical household hierarchies, which are dominated by men. While related to our work, this study does not explore how gender affects family communication practices. Instead, it presents a high-level overview of mobile phone access.

Research has also shown that expatriates who worked and lived in Nairobi creatively 'got around' issues of limited connectivity and power by preplanning their communications before accessing the Internet [35]. Some Kenyans have adopted social media despite infrastructural challenges. Facebook usage focuses on connecting with friends [36], but, perhaps more importantly, around income generation, such as finding a job [32]. Challenges with the use of Facebook included the costs of using a 'free' service (e.g., paying for connectivity), mobile phone battery power, and low bandwidth [36]. We also see the value of mobile phones for promoting trade, regional cooperation and development within East Africa based on education levels, poverty, and fears of technology [19].

Similar to our study, Wyche et al. [33] conducted a study with Kenyan migrants living in the United States and found they had difficulties connecting with their family members in Kenya because of the technological and infrastructure limitations [33]. They also found that many family members who moved away from Kenya to more developed countries still engaged in domestic activities in their home villages related to the remittance of money [33]. Mobile phones dominated communication routines and they described the use of 'beeping' [6] to notify remote family members to call them back [33]. Our work builds on this study by focusing on how people within Kenya connected with family members who were distributed across the country in a mixture of rural, suburban, and urban settings. Overall, our work builds on the related literature to focus specifically on family communication practices where we identify how and why technology is used and what social factors affect this communication. 


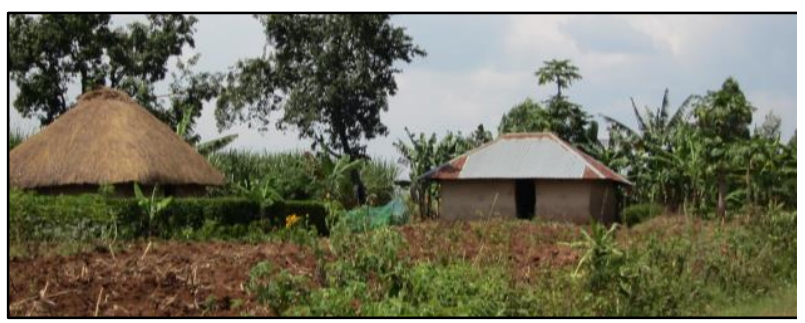

Figure 1. Migori: a rural home surrounded by land for subsistence cultivation.

\section{STUDY METHODOLOGY}

We conducted an interview-based study to understand: 1) how and why Kenyans used technologies to communicate with family members in rural, urban, and suburban areas, and 2) what social factors affected communication.

\section{Participants and Recruitment}

We recruited 24 people across three regions of Kenya. Participants were between 19 and 59 years of age.

\section{Study Site 1: Migori (Rural)}

Eleven participants (6 women) were from rural Migori, Our participants from this setting lived in Awendo, a rural part of the larger Migori District that lies $360 \mathrm{~km}$ from Nairobi with a population of $\sim 47,000$ [18]. Figure 1 shows a typical home in the rural part of Migori consisting of two or more huts built within the same compound and enclosed by a fence. Families in this region cultivate tobacco and plant sugarcane as cash crops while families that do not own large parcels of land engage in subsistence farming of maize, beans, coffee, groundnuts and vegetables. Polygamy is also practiced in this region. Education levels of our participants varied from no schooling to high school graduates. We also had a community leader, a woman who sold medicine without proper medical training as a chemist and a kindergarten teacher.

\section{Study Site 2: Kisumu (Suburban)}

Four participants (2 women) were from suburban Kisumu. Kisumu is a port city in western Kenya with a population of $\sim 400,000$ [15]. Kisumu is the major commercial center in Western Kenya. Fishing, agriculture (both large scale and subsistence sugar and rice cultivation), textile and fish processing industries are located in this city. Several offices of NGO's and commercial banks servicing the entire western Kenya region are also found here. Our participants from Kisumu included a businessman, a senior civil servant, and two recent university graduates.

\section{Study Site 3: Githurai (Urban)}

Nine participants (5 women) were from Githurai, a multilingual mixture of slums and suburbs that lies in the eastern part of Nairobi with a population of over 300,000 [10]. According to a World Bank report on Kenya, 47\% of the population lives below the poverty line characterized by lack of proper housing, poor infrastructure, poor access to health care facilities and lack of quality education [23]. Figures 2 and 3 show the range of homes of our participants in Githurai. On one hand, Figure 2 shows a home of a

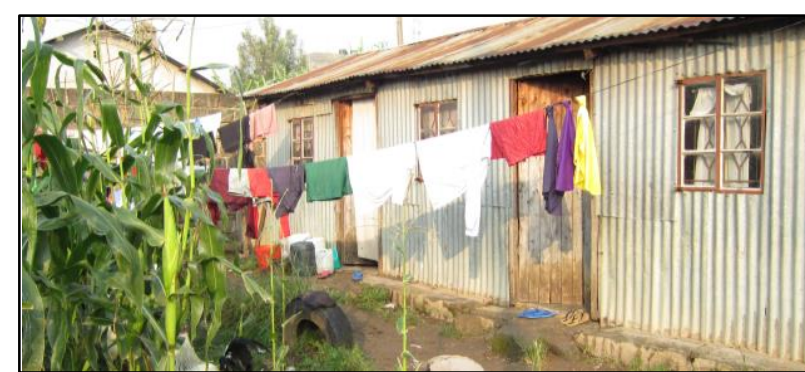

Figure 2. Githurai: a low income home.

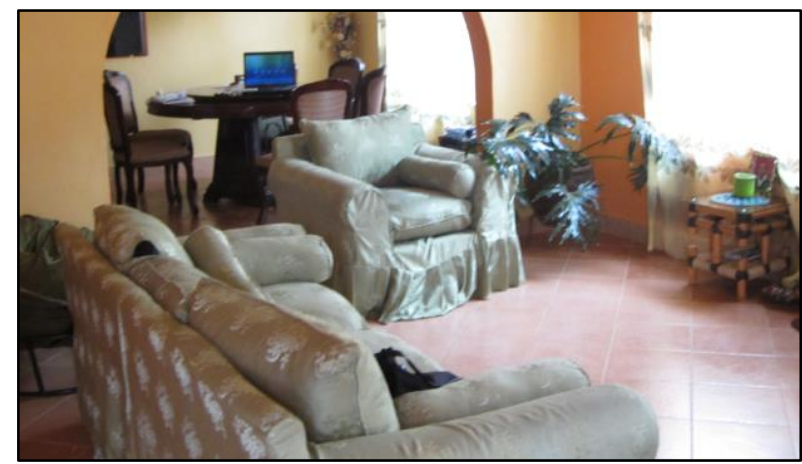

Figure 3. Githurai: a sitting room in a suburban setting with a laptop on a desk in the background.

participant who was selling fish by the roadside to make ends meet. Figure 3 shows the living and dining room in the home of a senior civil servant in a suburban area. People living in Githurai engage in merchandise sales in small retail shops, open air cloth stores, welding, carpentry, formal employment in the nearby Kenyatta University, and low-level administrative duties in government offices.

\section{Recruitment}

Three participants from Githurai and two from Kisumu were recruited through posts on Facebook and Twitter. The remaining participants from both regions were recruited through posters that were placed in small retail shops and by word-of-mouth. Our selection was iterative where we reached out to people of different occupations as we continuously learned about family practices.

In the rural settings, the community leader and chemist participants assisted us in identifying rural interviewees who had limited education. Participants were recruited through word-of-mouth and notices and posters that we displayed on the local village chief's office notice board and on the chemist shop entrance. After identifying our participants, the first author requested permission from the elders of the homes that we were to visit in cases where women were to be interviewed while their husbands were away or had passed on. This action was important since the elders had to be informed why the interviewer would spend time in the company of one's wife or a widow.

The first author has his ancestral roots in this community. As such, participants described wanting to have sustained involvement with the principal investigator's research. 


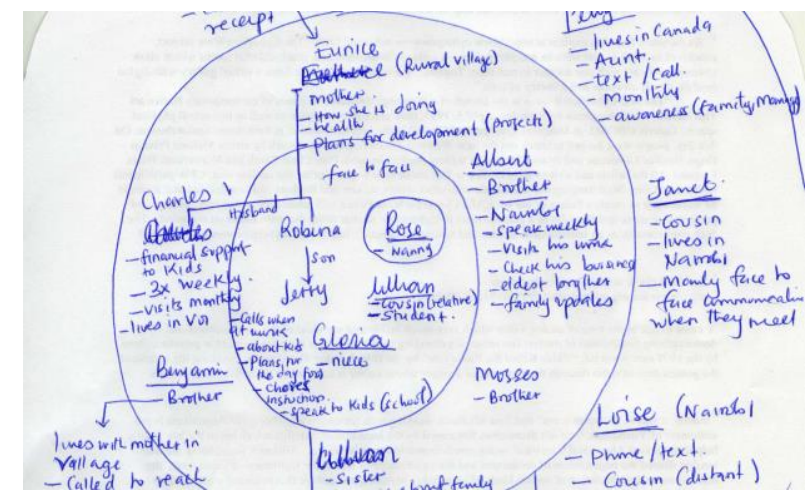

Figure 4. A participant's communication 'map'.

\section{Household Composition}

Eighteen participants lived with immediate family. Within this group, three participants lived with both immediate and distant family members under the same roof (one from the urban region and two from suburban regions) and two participants (from the rural setting) had two wives who both had young children aged between one to 10 years. The remaining six participants were either single or living alone.

\section{Technology Ownership}

Seventeen participants (10 rural, 5 urban and 2 suburban) owned a single mobile phone. On the other hand, seven participants ( 2 rural, 2 suburban and 3 urban) reported the ownership of more than one mobile phone where each phone was used for a different purpose. For example, one participant had a phone that he used to call family members and a second one dedicated for non-family related discussions. One rural participant owned a desktop computer that was kept in storage. Four suburban participants owned one laptop and two owned desktop computers. Three urban participants owned a laptop and six owned two laptops. Thus, we see only suburban and urban participants owned a form of computer, while rural participants relied primarily on mobile phones.

\section{Interviews and Home Visits}

We conducted semi-structured interviews with participants over the course of two visits. Each visit lasted between 45 and 60 minutes. During the first visit, the interviewer conducted an in-depth interview with the participant about his or her family and communication practices. Participants were provided with a sheet of paper and asked to draw their family communication networks. The investigator used information about kinship charts [12] to provide guidance. Participants filled in the type of technology and kind of information that was exchanged with their kin. Figure 4 shows a portion of a drawing created by a participant. Participants were then asked a series of questions about their communication routines with their family members. This included questions about when and how often a participant contacted each remote family member and what type of technology was used. The second visit happened approximately one week after the first visit where the investigator discussed findings from the first interview and asked follow-up questions.

Rural participants were interviewed within their homes while urban and suburban participants were interviewed either at their workplace or homes. One suburban participant was interviewed at his business premises, the senior civil servant at his home, while the university graduates were interviewed in their relatives' homes. Participants spoke in a range of dialects and languages, which were all understood (and later translated) by the first author who had lived in our study areas in the past. Overall, our participant selection gave insight into the family communication practices of five different tribes.

\section{Data Collection \& Analysis}

All interviews were audio-recorded and handwritten notes were kept. Our findings are based on 24 transcribed interviews, 69 photographs (depicting participants' homes and areas of communication) and 92 pages of field notes. We analyzed our interview transcriptions and notes using open, axial, and selective coding [28].

Our results are organized into two main sections. First, we outline the reasons participants used technology to communicate with immediate and extended family members. Second, we describe the social situations that influenced family communication routines and activities. All participant names have been anonymized.

\section{REASONS FOR COMMUNICATION WITH TECHNOLOGY}

Participants described communication routines with their immediate family (parents, spouses, children, and siblings) and extended family (nieces, nephews and cousins). The family members were either co-located or remotely located in other parts of the country (rural, suburban or urban).

In rural areas, family communication was focused around in-person exchanges and technology was used only occasionally to communicate with the people that one lived with. While out working in places such as the farms, most participants did not communicate with their family members unless there was an important message to discuss. Mobile phones would then be used to coordinate urgent matters.

In the suburban and urban regions, family members had more frequent opportunities for exchanges of information throughout the day through the use of technology. Across these three areas, we found that technology-based communication generally focused on four topics: economic support, life advice, well-being, and, sometimes, family coordination. We describe each next.

\section{Economic Support}

Like findings from previous studies [1,8,9,12,13,19,33], our participants reported that the most important reason for communication with technology was for economic support. This occurred frequently where people living in rural areas would communicate with their suburban and urban family members. This included situations such as parents receiving 
financial assistance through MPesa (also documented in [13]) from their adult children who were working away from home. There were cases where participants were supporting a niece or a nephew through payment of fees (also found in [20]) and even others where siblings and cousins were supported with money to sustain subsistence farming of small scale business endeavors. The use of MPesa to send money to aged and unemployed parents living in the villages was reported by seven participants ( 2 from suburban and 5 from the urban areas).

Moving beyond other study's findings, we also found that family members who were considered wealthy were more likely to have communication focus around economic support. This sometimes created feelings of obligation or emotional struggles because conversations tended to overlyfocus on economic support at the expense of other topics. For example, a successful suburban businessman explained to us that he felt obligated to financially assist both his immediate and extended family members.

\begin{abstract}
"Most of my family members see that I have a successful business, they always call me whenever they need financial assistance. Sometimes I call them too, but most of the discussions will end up on some sort of money needed somewhere. Because I am able to assist them most of the time, I do not have a problem with this. However, I do not remember one person who called me just to know how I am doing over the past four months." - Bosire
\end{abstract}

\section{Life Advice and Guidance}

Communication between rural and urban family members also focused on parents providing advice to children and siblings and close friends encouraging each other about the challenges of life. This was especially the case for parents of adult children who had moved away from home. For example, one participant who was a retired teacher explained to us that, together with his wife, they called their children who worked and lived in other urban regions around the country to provide advice on how to face marriage and life's challenges and problems. They also provided parental advice to their children on the importance of Christian fellowship to build a united family.

"This is because as parents, we feel obliged to make sure that they live respectable lives in whichever part of the world that they are in." - Chumah

In another situation, Lavender, a housewife living in rural Migori, described how she called her mother, sister and her childhood friend to discuss their marital challenges and difficulties.

\footnotetext{
"I communicate a lot about family life and express my love to both my mother and sister who lived away from me. I also do the same with my husband while I am away from home while visiting my mother, sister or other close relatives. We talk about the wellbeing of the kids and private family issues over the phone if there is need to do so. I also talk to my sister and close friends who are all married to discuss issues within our respective marriages over the phone. This helps us to get encouragement that will enable us to overcome our marital challenges." - Lavender
}

As a tailor, Lavender could not afford to spend much money on calling. She would reach out to her relatives and friends occasionally when she received extra income from repairing clothes in addition to finances that her husband would provide for family upkeep. Thus, her calls greatly depended on the availability of funds after ensuring that basic housing needs such as food, children's medicine, and school equipment such as books and pens for her children had been purchased. Her family and friends would also call her occasionally to know how she was faring on. She would call her friend to set up a meeting so that they could discuss the strains of marriage that resulted from adultery suspicion of their husbands, abuse and alcoholism, which was a pertinent issue in most young families in rural settings.

\section{Well Being}

We also found that family members used technology to communicate about the well-being of others. For example, two rural participants reported calling their children in urban areas of Kenya as well as in other countries abroad with a focus on understanding their well-being, e.g., troubling times, health issues. This also occurred for six urban participants. Thus, this practice was limited and only occurred for people who were considered to be in a better economic situation. It was also more secondary in terms of importance when compared to communication around economic support.

"Apart from my wife, the next important person that I talk to is my mother who lives in the village. She will always give me updates on how immediate family members are generally doing ... I also call my siblings every other time to check on the well-being of their families. I tend to call the others often since I am the eldest in the family. "'- Athanas

\section{Coordinating Family Activities}

For households containing multiple individuals, it was important to coordinate the daily activities of family members. Face-to-face interaction was the widely used mode of communication between such families. While rarer, there were specific cases where technology was used for coordination purposes.

In rural settings, technology was not widely used for family coordination because it was too costly or simply not needed (since family members would see each other in person in the morning and evening). Instead, only people who had specific jobs that required them to use a mobile phone for work would do so. For example, George used his mobile phone while conducting his motorcycle taxi business to run small errands for his family members who lived in the village with him. He received calls from either of his two wives (whoever had enough credit for calling), his mother or his siblings (or their wives) who lived in the village while driving customers on his motorcycle. They would ask him to buy commodities such as bathing soap or sugar packs while taking customers to or from Awendo. $\mathrm{He}$ would then purchase the requested commodity and bring it home if he was dropping a customer off close to his home. 
Second, suburban and urban participants who lived with other family members used technology more often for coordinating family activities in comparison to the rural participants. Parents reported using technology to get in touch with their children for shopping, dinner planning, and household chores. For example, Alice lived in the slums of Githurai and sold fish in the evenings after $5 \mathrm{pm}$ to those returning home from work in the city and its environs. This meant that she would be at her stall while her teenage children returned home from school. Her eldest daughter owned a phone and would beep her since she did not have phone credits to actually place the call. Alice would then call back. Phone conversations focused on instructions to the children about what to do around the home, such as purchasing food for dinner and cooking it.

In another example, a suburban participant and senior civil servant was constantly travelling for training across the country. He bought mobile phones for all of the adults in his household so that whenever he called he could reach his children (age 10 to 16). In these cases, he wanted to ensure that the children were working on their school assignments or chores that had been assigned by their mother.

\section{SOCIAL SITUATIONS AND CHALLENGES}

Like other research [33], we found communication was often timed based on cheap calling time periods, when lots of family members would be present, an individual's economic situation, and electricity availability. We also saw instances of beeping, 'please call me texts,' and a focus on conversation brevity [33,34]. Beyond these practices, we also learned about various social situations, described next, that affected family communication routines ranging from being the eldest child, to supporting the families of deceased siblings (different than in [22]), to gender.

\section{Eldest Children}

Generally, parents were in charge of coordinating family activities. However, the dynamics of this situation changed when adult children moved away from the rural areas and migrated to suburban or urban areas. In these situations, parents would entrust the eldest children with the duty of passing information to their siblings who were also working or studying away from the rural villages.

For example, four participants (one female) who reported to be the eldest in their families were always prepared to communicate with any member of their family in case an emergency or important issue arose. Issues ranged from holding discussions aimed at solving an economic problem that needed financial intervention or even engaging in a serious discussion to solve family disputes and quarrels. Because of this, the eldest children (from our participant pool) who all lived in Githurai often felt obligated to have their mobile phones on as much as possible in order to receive information from their rural village and then share the same with dispersed family members. If the eldest child worked at a job that did not allow them to be constantly available, messages would then be shared through other family members. But seniority in terms of age, would dictate who was expected to handle sharing such messages.

"As the eldest in my family, my phone must always have credit because I have to keep in touch with my parents who live upcountry. I am always the first one they will contact if there is any information that needs to be sent to my brothers and sisters who live away from home. I also receive calls at any time from my siblings and extended family. My phone must be on all the time to ensure that I am able to receive all information and then pass any important ones to other family members." Julia

Sometimes this created additional monetary burdens on the eldest children. If cases arose where one of the adult children was more financially well off than the eldest child, the obligation as 'information hub' moved to this child. For example, in one case, a civil servant participant who was seen to be financially well off in comparison to her eldest brother was expected to disperse information from her mother in the village to her siblings who lived in Nairobi.

\section{Death and its Effects on Communication}

We were also told about ways in which surviving relatives who worked away from home would use scarce financial resources to communicate with the families of their deceased siblings left behind in rural homes. This was a cultural obligation described by our participants.

For example, a participant named Opana who was in his early fifties was the only surviving male out of his entire family. His parents and siblings had all passed away and he lived in Githurai with his wife and six children. Opana was a low income clerical civil servant and lived on a very tight budget. He had to take out loans to meet his financial obligations and also engaged in a small tailoring business in the evening after work and during the weekends to make ends meet. Despite this, Opana was still culturally responsible to communicate with his siblings' widows to ensure the smooth running of the rural home as the surviving eldest male in his extended family.

Opana purchased mobile phone credits worth $\$ 0.60$ (Kshs 50) to make phone calls whenever his siblings' widows from the village beeped him or sent him a please call me message. He would then call between $8 \mathrm{pm}$ and 6 am when the special Telkom service provider rates could allow him at least 20 minutes worth of 'talk time' for this amount of money. To get the best value out of the discussion using the little phone credit available, he would let the eldest widow briefly explain the issue at hand before quickly giving his opinion and advice over the matter. This happened at least once or twice a month unless there were other pressing issues that required continuous consultation such as planning to attend a relative's funeral. In such cases, there would be a brief exchange of updates every now and then in an attempt to coordinate issues.

\section{Gender}

We also found that gender affects family communication practices. First, we found that women often had to rely on their husbands for access to mobile phones; Murphy and Priebe [21] also report this finding. Building on their work, 
we saw how husbands and wives created workarounds in order facilitate communication.

First, we found that husbands often used their male siblings as communication 'intermediaries' when they wanted to initiate communication with their wives. In cases where one's wife did not have a phone in their possession, the husband would contact his other male siblings in order to reach his wife. Thus, gender played a dominating role in who would be contacted as an intermediary in order to connect with one's wife. For example, two male participants in the rural setting reported that their wives did not own mobile phones. In one case, the participant and his wife would share one phone, though it routinely stayed with the husband. Thus, he claimed 'ownership' over the device. The other participant reported that in addition to sharing his phone with his wife, he would occasionally call his siblings to reach his wife in case he was away from home for casual work. This meant that rather than being able to directly contact his wife to converse, he relied on other people, specifically his male siblings.

"When I am away from home and need to speak to my wife on the phone, I will call my brother and ask him if he is able to pass his phone to my wife so that I can speak to her in private. Once our discussion is finished, she will return the phone and thank my brother." - Atandi

Second, we learned that some women would purchase SIM cards to enable them to call family members. SIM cards were cheaper than mobile phones and easier to conceal from husbands, if needed. For example, one female participant told us that she kept a SIM card with a small amount of phone credit on it (e.g., Kshs 20) in case she needed to contact a relative. She would borrow her husband's phone to call her female family members (e.g., sisters). This sometimes included sharing information about her husband to a close family member without the husband's knowledge. Her husband was aware that she kept her own SIM card and would occasionally ask to use it if he did not have enough credit on his own phone. In case her husband was out with his phone and the participant needed to make a call, she would walk for about 20 minutes to borrow a handset from her brother in-law's wife. This example reveals the ability to have communication access without the need to have a phone per se. Instead, one can use shared phones and a personally owned SIM card. It also reveals the lengths and 'workaround' strategies that women might go to in order to communicate with other female family members to gain life advice.

Third, we found that female participants who lived in urban or suburban areas were more likely to own mobile phones on their own. In some low income families, they often had to conceal their use of it from their husbands. For example, a female participant who was running a small scale fish selling business told us about the use of her mobile phone for discussing financial discussions with her sister. Her sister would supply her with fish from their rural home, and then deliver the fish overnight by a bus to Githurai. What was interesting about this case was that all communications between the participants and her sister had to be done without the participant's husband knowing.

"When I need to discuss my business progress with my sister, I have to make sure that my husband is not around the house if I have to make that call." - Rose

She explained that this secrecy was necessary because if her husband overheard communication related to profits, he would stop providing money for use within the house and let her take care of such expenses. This could result in her business 'going under' since she made little profit which was mainly used to support poor family members who lived in the village. Thus, she delicately negotiated the unequal relations of economic power with her husband through economic discussions without his knowledge.

\section{Phone Sharing and Connecting through Intermediaries}

Like other research [27,34], we also found that rural participants shared phones because of a lack of ownership, loss of service network, and a lack of battery power. On the other hand, urban and suburban participant did not report sharing of phones because of better infrastructure and ability to purchase additional phones. This finding is different from [27], where factory workers shared phones in urban areas mainly due to lack of cellphone ownership in urban India. In our case, Phone sharing created several interesting social situations.

First, shared phones created additional obligations on others to pass along messages. For example, we found that, in some cases, if a person being sought after was not available, the receiver would take the information over the call and then share it with the relevant family member later. This information had to be remembered or written down and later shared. If the information was private and only intended for the recipient, the caller would ask the owner of the mobile phone to alert him through a "please call me" message or a beep whenever the intended recipient of the message was located. This created additional work for the owner of the phone who would then receive replies to the "please call me" and have to transfer the information to call back the original caller.

Second, urban participants reported that they frequently faced network problems while trying to reach their relatives in rural areas. Some participants said they would keep trying until they were able to connect. Another practice was to try calling other family members, starting from immediate family including siblings and then progressively moving out to cousins and other relatives until a person was reached. Once they got a hold of someone, they asked them to tell the person being sought to get in touch with the individual calling from the urban area. Again, this created additional work beyond simply contacting one individual. Such behaviors were reported by seven urban and two suburban participants. The idea of calling people and asking them to pass on information was a practice that all the rural participants engaged in and understood to be the norm. 


\section{Computer Literacy and Finances}

All participants communicated with their family members by calling on mobile phones. Urban and rural participants did not typically use text messages for communicating with one another because, in most cases, an immediate response was required due to a heavy focus on economic support. As a result they relied on voice communication. Illiterate participants also relied on voice communication because they simply could not read or write text messages.

We also found that one's financial situation affected what technologies were owned and used. While mobile phones were certainly the most popular communication tool, some urban participants also used computers, social media, and video conferencing to communicate with remote family members. This was because they were typically more financially well off than their rural family members. It also meant that computer-based communication did not occur between urban and rural areas because those in rural regions could often not afford computer technology and, even if they could, infrastructure issues and a lack of electricity, would create usage problems. Instead, computers were primarily used to connect with family members living abroad. For example, five urban and four suburban participants used their own laptops to connect to the Internet to send emails and use social media such as Facebook for chatting. This occurred either in their home or workplace and communication was mainly with family living outside of Kenya. Two suburban graduates reported the use of social media on their phones in addition to laptops to chat with their sibling, cousins and friends who lived within the country and abroad.

Computer literacy varied amongst our participants. Four urban participants and eight rural participants reported that they did not know how to use computers either due to lack of education or lack of motivation, while four rural participants mentioned that they had basic experience with computers. The distance to cyber cafes from rural areas $(\sim 20 \mathrm{~km})$ made it difficult for computer literate participants to access the Internet (also reported in [33]). Other lowincome participants would have been willing to gain knowledge in using computers but other economic related challenges seemed more important at present. Similar observations were also made in the outskirts of the urban areas where older participants who did not have prior experience with using technology thought it was not worth spending time to learn something that would not improve their lives economically.

\section{DISCUSSION AND CONCLUSIONS}

The goal of our study was to articulate the family communication practices of our participants with a focus on understanding when technology was used and why, and what social factors affected this usage. In this section, we point to design implications. We caution, however, that our implications are not focused on presenting guiding ideas for how to design technologies. We feel that any such discussion would be preliminary and speculative at this point. Instead, we suggest areas that present further design opportunities which move beyond the suggestions of previous work. We also outline the social challenges that designers will need to carefully think through when creating or deploying family communication technologies in Kenya.

\section{The Focus of Communication}

Technology-based family communication in the areas of Kenya that we studied focused largely on four main areas: providing and discussing economic support, life advice and guidance, maintaining an awareness of well-being, and, sometimes, the coordination of everyday family life. At a surface level, these results illustrate the areas where technology design for family communication in Kenya should be targeted.

Other research has suggested the coupling of financial transactions with communication [36] as a starting point for family communication design. Our results shed light on the idea that while economic support was critical to life in Kenya for most of our participants, they also found value and participated in communication exchanges on other topics that helped create a sense of well-being and allowed them to discuss, gain advice, and come to terms with life challenges (sometimes even related to their own spouses). This suggests a broader understanding of what family communication practices may be important for Kenyans. Solely focusing technology design on providing economic support may neglect the 'human' need of connecting with others for less utilitarian purposes. Certainly Kenyans need to earn money and negotiate financial help from remote family members, but they also have inherent human needs that need to be filled through the connection with others.

\section{Social Challenges}

We also found that a variety of social situations affect how families communicated using technology. First, we found that additional pressures are placed on the eldest children in the family and the siblings of widows to connect with family members. In these situations, Kenyans were socially and culturally obligated to stay aware of the activities of additional family members and coordinate the exchange of information. This presents results that move beyond past work that shows the obligations faced by those family members who are considered to be more 'well off' financially [33] to show what additional social factors affect cultural obligations.

This brings forward the idea that new technology designs will be used differently by users depending on their social role within a family. It also suggests design opportunities based on social roles. For example, the eldest children in a family may need technologies that allow them to easily be available on a continuous basis, while not being overwhelmed by such connectivity. Such technologies could be focused around the user as an information hub who frequently receives and sends-on information about a wide variety of family members. In another situation, the eldest males in a family containing widowed in-laws may value technologies that provide awareness information 
about the well being of the widows. Technologies for users who are not in these more demanding social roles may need to support less frequent information exchange between family members.

Second, we found that access to technology and usage will differ between men and women, those with different literacy rates and computer experience, and those with different levels of technology access due to connectivity and finances. This illustrates that technology cannot be designed with a 'one size fits all' mentality. Moreover, designers should consider how any future designs might affect these social and cultural issues. For example, one would need to carefully navigate the delicate gender balance and cultural norms related to social hierarchies in families. In this case, while it may seem beneficial to design technologies specifically for women, doing so could easily create an undesired shift in the traditional malefemale roles found in Kenyan families. Gender is a very complex subject with many subtleties and certainly this aspect requires additional research.

We also found a contrast in computer accessibility, use, and knowledge between participants in rural and urban regions. Thus, our study draws attention to a 'digital divide' within Kenya. In rural areas, a large number of participants did not have knowledge about computers. This was partly because they were occupied with subsistence farming and small-scale income generating activities that were barely enough to support gaining knowledge about computers. On the other hand, the working class (civil servants and business men), college graduates and, to some extent, low income individuals living in urban areas were already using more advanced communication technologies (e.g., Facebook, Skype).

The challenge is that the rural and urban areas have different technological infrastructure, education, and understanding of computers. There will continue to be a disparity that needs to be designed around if family members are to easily communicate between rural and urban areas. Currently, mobile phones support this because they are simple to use. Yet as technology advances, in particular in the cities, designs may move away from mobile phones to other devices such as computers. This could easily create a new challenge for family communication in Kenya. Even though the family communication routines we uncovered in our study were specifically tied to mobile phones, it is likely that existing practices (e.g., a focus on economic support) will stay consistent as new technologies are introduced and developed in Kenya. This is because they are culturally specific and reflect the ways in which Kenyans need to communicate when separated by distance. This creates a challenge where researchers and designers of technologies will need to understand how to translate the cultural practices of Kenyans to the next wave of technological advancements to continue to create technologies that are uniquely Kenyan and balance disparities in education levels, income, electricity, and connectivity.

It is also likely that the future will hold new opportunities for the design of applications in Kenya that utilize the Internet and may even mean the creation and further adoption of social networking sites and rich communication systems such as video chat. However, it is not necessarily the case that such technologies will migrate from developed countries to developing countries on the simple basis of improved infrastructure where the use of these technologies is the same in Kenya as other developed countries. Instead, we feel that one should think carefully about the ways in which Kenyans are likely to need and use communication technologies and specifically design for such situations.

\section{Study Limitations}

We recognize that while valuable, our study results do come with their limitations. Our work should certainly be complemented by additional studies in other developing countries around the world. We focused on a country that is highly multicultural with many different ethnicities and village types. Other areas of Kenya beyond which we studied have different economic foci that do not contain subsistence farming. For example, some regions engage in fishing, hunting, pastoral work, etc. Other areas of Kenya also do not contain polygamy as a cultural practice. We also only investigated Kenyans from five tribes (out of a potential 42) [14], mainly drawn from western Kenya. Thus, the communication practices that we found may differ for these areas. This suggests additional investigations into family communication routines in other parts of the country and with additional tribes. Such studies will enrich our knowledge in understanding the dynamic family communication needs of a larger representation of similarly marginalized communities.

We will continue to explore this design space where we plan to prototype technologies that will provide our participants with opportunities to engage in audio, text, and, to some extent, video communication with their distributed relatives. We aim to understand how such avenues will support our participants in their communication routines.

\section{ACKNOWLEDGMENTS}

We thank NSERC and the GRAND NCE for funding this research. We also thank past reviewers for their helpful comments on revising this paper.

\section{REFERENCES}

1. Agesa, R.U. and Kim, S., "Rural to urban migration as a household decision: Evidence from Kenya," Review of Development Economics 5, 1 (2001), 60-75.

2. Best, M., Smyth, T. N, Etherton, J. \& Wornyo, E. Uses of Mobile Phones in Post-Conflict Liberia. Inf. Tech. \& Int'l Development Vol 6, (2) (2010), 91-108.

3. Bidwell, N.J. \& Siya, M.J. Situating Asynchronous Voice in Rural Africa. Proc. INTERACT, Springer, (2013), 36-53. 
4. Bidwell, N.J., Lalmas, M., Marsden, G., Dlutu, B., Ntlangano, S.,Manjingolo, A., Tucker, W.D., Jones, M., Robinson, R., Vartiainen, E., Klampanos, I. Please call ME.N.U.4EVER: Designing for 'Callback' in Rural Africa. Proc. IWIPS'11, (2011), 117-138.

5. Burrell, J., Evaluating Shared Access: social equality and the circulation of mobile phones in rural Uganda, Journal of Computer-Mediated Communication, 15(2), (2010), 230-250.

6. Donner, J., "The Rules of Beeping: Exchanging messages via intentional "missed calls" on mobile phones, Journal Computer Mediated Communication, 13 (1), ACM Press (2008), 1-22.

7. Eriksson, E., A Case Study About Cell Phone Use by People in Rural Keyna, Vaxjo University, School of Mathematics and Systems Engineering Bachelors Degree Thesis, Apr 2008,IV9003.

8. Francis, E., (2000) Making a Living: Changing Livelihoods in Rural Africa. Routledge, London.

9. Ginsburg, F. Rethinking the Digital Age, in Global Indigenous Media: Cultures, Poetics, and Politics, Wilson, P. and Stewart, M. (Eds.), Duke University Press (2008).

10. Githurai Community. A Kenyatta University-Githurai Partnership http://www.ku.ac.ke/Githurai/index.html.

11. Horst, H. Blessings and burdens of communication: cell phones in Jamaican transnational social fields, Global Networks, 6, 2, (2006), 143-159.

12. Horst, H. and Miller, D. From Kinship to Link-up: Cell Phones and Social Networking in Jamaica, Current Anthropology, 46, 5, (2005), 755-778.

13. Hughes, N. and Lonie, S., M-PESA: Mobile Money for the 'Unbanked' Turning Cellphones into 24-Hour Tellers in Kenya, Innovations: Technology, Governance, Globalization 2, 1-2 (2007), 63-81.

14. Tribes in Kenya http://www.kenyanview.com/ Kenyan tribes/kenyaweb.htm

15. Kisumu. http://en.wikipedia.org/wiki/Kisumu

16. Kwake, K. and Adigun, M., Analyzing ICT use and access amongst rural women in Kenya, International Journal of Education and Development using Information and Communication Technology (IJEDICT), 2008, Vol. 4, Issue 4, pp. 127-147.

17.Liu, J., Liu, Y., Rau, P.-L.P., Li, H., Wang, X. and Li, D., How Socio-Economic Structure Influences Rural Users' Acceptance of Mobile Entertainment, Proc. CHI, ACM Press (2010), 2203-2212.

18. MigoriTown.com http://migoritown.com/

19. Mimbi, L., Bankole, F., and Kyobe, M. Mobile Phones and Digital Divide in East African Countries, Pr.c SAICSIT, ACM Press (2011).

20. Morawczynski, O., and Pickenism, M-PESA: More Than Money Transfer, www.mobilepaymentsworld.com /m-pesa-more-than-money-transfer-by-olga-morawczy nski-and-mark-pickens/. Mobile Payments World, Accessed 9th September 2013.

21. Murphy, L and Priebe, A. 'My co-wife can borrow my mobile phone!': gender geographies of cellphone usage and significance for rural Kenyans, Gender Technology and Development, March 2011, Vol 15, No 1, 1-23.

22. Peters, A., Oren, M. and Bidwell, N., Namibian and American Cultural Orientations Toward Facebook, Proc. CHI, ACM Press (2012).

23. Poverty Overview, http://www.worldbank.org/en/topic/ poverty/overview.

24. Rangaswamy, M. and Sambasivan, N. Cutting Chaai, Jugaad and Here Pheri: towards UbiComp for a global community, Personal and Ubiquitous Computing, 15(6), Springer (2011).

25. Sambasivan, N., Cutrell, E., Toyama, K., and Nardi, B. Intermediated Technology Use in Developing Communities. Proc. CHI, ACM Press (2010).

26. Sambasivan, N., Rangaswamy, N, Cutrell, E., and Nardi, B. Ubicomp4D: Infrastructure for International Development-the case of Urban Indian Slums. Proc. CSCW, ACM Press (2009).

27.Smyth, T., Kumar, S., Medhi, I. and Toyamo, K., Where There's a Will There's a Way: Mobile Media Sharing in Urban India, Proc. CHI, ACM Press (2010). 753-762.

28.Strauss, A. and Corbin, J., Basics of Qualitative Research, 2nd Edition, Sage Publications (1998).

29. Taylor, A., Out There, Proc. CHI, ACM Press (2011).

30. Vertovec, S. Cheap Calls: The Social Glue of Migrant Transnationalism. Global Networks 4, 2, (2004).

31. Williams, A., Anderson, K., and Dourish, P. Anchored Mobilities: Mobile Technology and Transnational Migration. Human Factors, Proc. DIS, ACM Press (2008), 323-332.

32. Wyche, S., Forte, A. and Yardi, S. Hustling Online: Understanding Consolidated Facebook Use in an Informal Settlement in Nairobi, Proc. CHI, ACM Press (2013).

33. Wyche, S. and Grinter, R. "This is How We Do it in My Country": A Study of Computer-Mediated Family Communication Among Kenyan Migrants in the United States, Proc. CSCW, ACM Press (2012).

34. Wyche, S. and Murphy, L. "Dead China-Make'” Phones Off the Grid: Investigating and Designing for Mobile Phone Use in Rural Africa, Proc. DIS, ACM Press (2012).

35. Wyche, S.P., Smyth, T.N., Chetty, M., Aoki, P.M. and Grinter, R.E., Deliberate Interactions: Characterizing Technology Use in Githurai, Kenya, Proc. CHI, ACM Press (2010), 2593-2602.

36. Wyche, S., Yardi, S., and Forte, A. "Facebook is a Luxury": An Exploratory Study of Social Media Use in Rural Kenya, Proc. CSCW, ACM Press (2013). 